\title{
A WORKFLOW FOR BUILDING SITE DIGITALIZATION
}

\author{
GIUSEPPE MARTINO DI GIUDA ${ }^{1}$, GIULIA MARCANDALLI ${ }^{2}$, LAURA SANVITO², \\ MARCO SCHIEVANO ${ }^{2}$, and FRANCESCO PALEARI ${ }^{2}$ \\ ${ }^{I}$ Dept of Management, Università degli studi di Torino, Torino, Italy \\ ${ }^{2}$ Dept of Architecture, Built Environment and Construction Engineering, Politecnico di \\ Milano, Milano, Italy
}

\begin{abstract}
The digitalization of construction sector is becoming increasingly important. Based on European Community Directives, Italian legislation has defined a national strategy to start the process of digitization of the construction and public works sector. The purpose of this paper is to set a method for the digitalization of the building process, schematizing the workflow of the procedures that regulate construction management activities. A careful analysis of the state of the art of construction phase activities regulations is carried out; this analysis was based on construction management manuals, scientific publications, and direct contact with professional figures who are related to Construction Management. Critical issues have emerged due to the complexity of the process, bureaucracy, and the digital transition of the sector. The stakeholders involved, the phases, the activities, the documentation, and the timing of the process were identified and represented graphically through the Business Process Model and Notation (BPMN). The advantages of the methodology are reported in relation to the goals of speeding up and improving the development of the building process, not only for the correct sequence of activities but also for the digital management of documentation. The workflows were standardized for a first implementation on the case study of a Secondary School, where this process helped the structuring of the collaborative platform for the creation of the Document Management System that was used during construction phases.
\end{abstract}

Keywords: Construction management, Digital approach, Italian legislation, Public procurement, Process analysis, Procedures.

\section{INTRODUCTION}

Digitalization is increasing its relevance in every sector, including construction. The adoption of digital and innovative tools is changing practices and approaches of the traditional information process, leading a shift from a system based on graphic representation, paper or digital, to a system of information models (Marcandalli and Sanvito 2020). Digitalization is characterized by information sharing, flow transparency, waste elimination, and the reduction of variants and disputes.

The digital transition in the construction sector is slow if compared to other manufacturing sectors, as highlighted by the digitalization index of the latest McKinsey Global Institute report of 2017. Even ISTAT (Italian bureau of census) in the 2018 report on the competitiveness of the production sectors, identifies a very low inclination to digitize the sector, at least in Italy (McKinsey 2017, Istat 2018, Ciribini 2019). Since 2014, the European Union has issued Community Directives (23-24-25/2014/EU) to change the shape of public contracts by pushing 
for digitization. This has led to new regulations at national level. Therefore, in terms of digitization, the current challenges of the AEC sector include integration between BIM and digital construction site, data transfer to building management and maintenance platforms and development of augmented reality. The need to define a national strategy for digitization in construction and public work sector is therefore evident. This methodology would help in repairing the fragmentation that is tearing down the construction sector and reducing productivity, as noted by Eastman and Sacks. Although the current context requires considerable efforts to make a digital transition to the efficient adoption and use of information modelling, a modernization of legal and contractual aspects of public procurement is also needed (Eastman et al. 2008).

\section{STATE OF THE ART}

\subsection{The Construction Management in the Traditional Building Process}

Building processes are complex systems, composed of a large number of different subjects, activities, and skills that follow and intertwine.

The research conducted by the authors was mainly based on consultation of technicalprofessional books (Gottfried and Di Giuda 2011, Gottfried 2013), technical manuals (Agliata 2016, Malosetti 2019), analysis of legislative frameworks and direct discussions with professionals who usually carry out the work of Construction Management offices. Peculiarities of building processes can be summarized in:

- Nonlinearity

- Inclination to mistakes

- Deadlines not always respected

- Incompleteness of information

- Bureaucracy: the building process is furtherly complicated by bureaucratic practices, which often involve a significant slowdown in the timing.

Neglecting the proper implementation of the workflow can negatively affect not only the administrative aspect, but can also lead to slowing down or interrupting construction site activities.

\subsection{State of the Art of the Legislation in Terms of the Construction Management}

Main legislative references are summarized in the following table.

Table 1. Italian Legislation in force.

\begin{tabular}{lll}
\hline Standard code & \multicolumn{1}{c}{ Standard title } & \multicolumn{1}{c}{ Content } \\
\hline $\begin{array}{l}\text { D.lgs. 18 April 2016, } \\
\text { n.50 }\end{array}$ & Codice degli appalti & $\begin{array}{l}\text { They introduce in the Italian Legislation the } \\
\text { theme of information modeling to be used } \\
\text { to digitize the construction and public } \\
\text { works sector }\end{array}$ \\
$\begin{array}{l}\text { D.lgs. 19 April 2017, } \\
\text { n.56 }\end{array}$ & Disposizioni integrative e correttive & \begin{tabular}{l} 
work \\
\hline
\end{tabular}
\end{tabular}

Table 1. Italian Legislation in force (contd).

$\begin{array}{ll}\begin{array}{l}\text { D.M. } 7 \text { March 2018, } \\ \text { Approvazione delle linee guida sulle } \\ \text { modalità di svolgimento delle funzioni }\end{array} & \begin{array}{l}\text { It regulates the activities carried out by the } \\ \text { Construction Manager, focusing on digital }\end{array} \\ \text { Co.49 }\end{array}$




\begin{tabular}{|c|c|c|}
\hline & $\begin{array}{l}\text { del direttore dei lavori e del direttore } \\
\text { dell'esecuzione }\end{array}$ & transition. \\
\hline $\begin{array}{l}\text { L. } 14 \text { June } 2019 \text {, } \\
\text { No. } 55\end{array}$ & $\begin{array}{l}\text { Disposizioni urgenti per il rilancio } \\
\text { del settore dei contratti pubblici, per } \\
\text { l'accelerazione degli interventi } \\
\text { infrastrutturali, di rigenerazione } \\
\text { urbana e di ricostruzione a seguito di } \\
\text { eventi sismici }\end{array}$ & $\begin{array}{l}\text { It introduces urgent provisions that should } \\
\text { foster economic growth and boost the } \\
\text { productive system by taking measures to } \\
\text { simplify the regulatory and administrative } \\
\text { framework related to public entrustment. }\end{array}$ \\
\hline $\begin{array}{l}\text { D.P.R. } 5 \text { October } \\
\text { 2010, n.207, art. } 9 \text {, } \\
\text { 10, 14-43, 60-96, } 215- \\
238)\end{array}$ & $\begin{array}{l}\text { Codice dei contratti pubblici relativi } \\
\text { a lavori, servizi e forniture in } \\
\text { attuazione delle direttive 2004/17/CE } \\
\text { e 2004/18/CE }\end{array}$ & $\begin{array}{l}\text { They contain information about the } \\
\text { contents of the design, the business } \\
\text { qualification system and } S O A \text { and the } \\
\text { testing. }\end{array}$ \\
\hline- & $\begin{array}{l}\text { Linee guida ANAC sulle modalità } \\
\text { operative e gli atti con cui devono } \\
\text { operare gli operatori del settore } \\
\text { (ANAC 2016) }\end{array}$ & $\begin{array}{l}\text { They provide interpretive and operational } \\
\text { guidance to industry operators to simplify } \\
\text { and standardize procedures, ensure } \\
\text { transparency and efficiency of } \\
\text { administrative action, encourage } \\
\text { competition and reduce litigation. }\end{array}$ \\
\hline
\end{tabular}

\section{MANAGEMENT OF WORKS PROCESSED ACCORDING TO REGULATIONS}

The existing regulatory framework stresses the relevance of digital management of accounting of works and control in execution of building works. This means that, in order to better integrate digital procedures in construction processes, professionals should base their activities on cooperation and information sharing. As for now, there are no standardized workflows that could help in overcoming information losses and mistakes.

The definition of structured and standardized processes can facilitate this shift: for this reason, this paper provides a flow that outlines the construction process and describes activities of Construction Management office. The scope of this paper is limited to public procurements and mainly focus on construction phase. The definition of structured procedures can help in facilitating and controlling the process, increasing its productivity by controlling uncertainty factors and preventing risk situations.

\section{METHODOLOGY}

The suggested framework differs from other existing methods for the digitization of construction processes that usually are limited to some phases, and mainly focusing on project-related activities. This flow reports in a complete and linear way the entire construction process concerning a public work. The proposed flows were designed following a detailed state-of-theart analysis of the legislation and literature that regulate the activities of Construction Management office. In particular, the research was mainly based on references cited in paragraph 2.1 .

\subsection{Workflow Structure}

The workflow illustrates the procedures that guide the interaction among the Construction Management office and the subjects involved in the stages of the process (tender, work delivery, construction, controls, end of works, and commissioning). This workflow allows the Construction Management office to closely follow the sequence of events and therefore ensure a timely control of the whole process. 
To define this flow, actors involved in the building process have been identified as Unique Procedure Manager, Construction Management office, Construction Companies, Contract Execution Director, Safety Coordinator in the Execution phase. The actions to be performed by each entity during construction phases have been identified, with a focus on documents related to checks, verifications and authorizations with related obligations and responsibilities, and the provisions and indications provided by above-mentioned standards.

Since the identified figures have to interact with each other, it was crucial to organize the flow in such a way as to respect the timelines and relationships between the actions of each subject.

However, there are processes that cannot be entered at a given time, but can be carried out for the duration of the construction site or that have a cyclical frequency. To overcome this problem during the control phase, "boxes" have been used that report these parallel processes. In particular, they refer to the operations necessary for:

- Site inspection

- Variations

- Accounting

To properly represent the process, a Business Process Model and Notation (BPMN) was adopted, in accordance with ISO 19510. The BPMN is a graphical representation for specific operational processes within a global business process model. BPMN allows to understand the procedures in a graphical notation, and gives the ability to communicate these procedures in a standard method. This ensures that all actors understand their own activities and those of the other actors involved, allowing for rapid adaptation to the site management system.

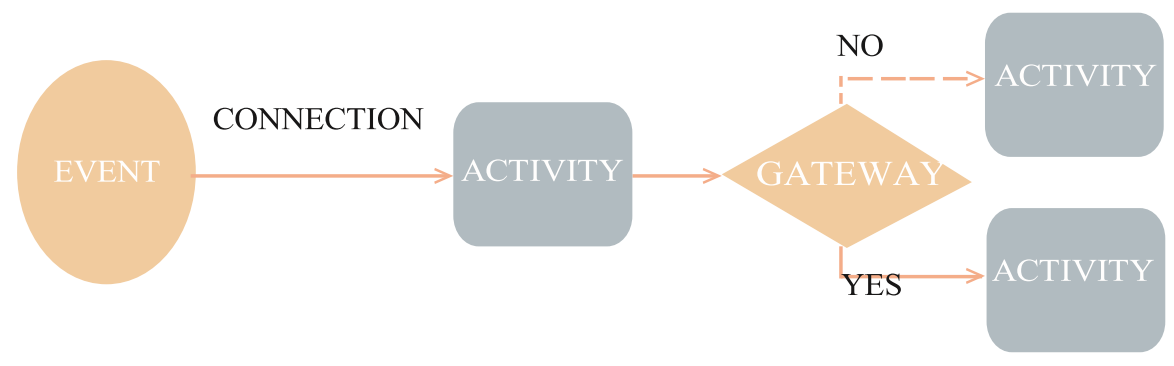

Figure 1. BPMS Structure.

All possible eventualities are represented, identifying the situations of choices through gateway. Gateways perform a first process control function, in which only two possible answers (YES/NO) are connected to each question. Gateways lead to a sequence of actions that can continue, or, in case of non-compliance, stop, leading to further actions to proceed with the process.

To optimize the management and control of the construction site from an administrative point of view, each action has been associated with the necessary documentation; at the same time, any statutory deadline related to such documentation have been entered.

To create the workflow, Microsoft Visio was used and, subsequently, Mindjet Mind Manager that, in addition to the flow diagram, allows inserting the direct link to the documentation inserted as an external file.

Figure 2 shows an extract of the workflow, related to tender phase. The workflow is divided in columns corresponding to the responsible person of each action. 


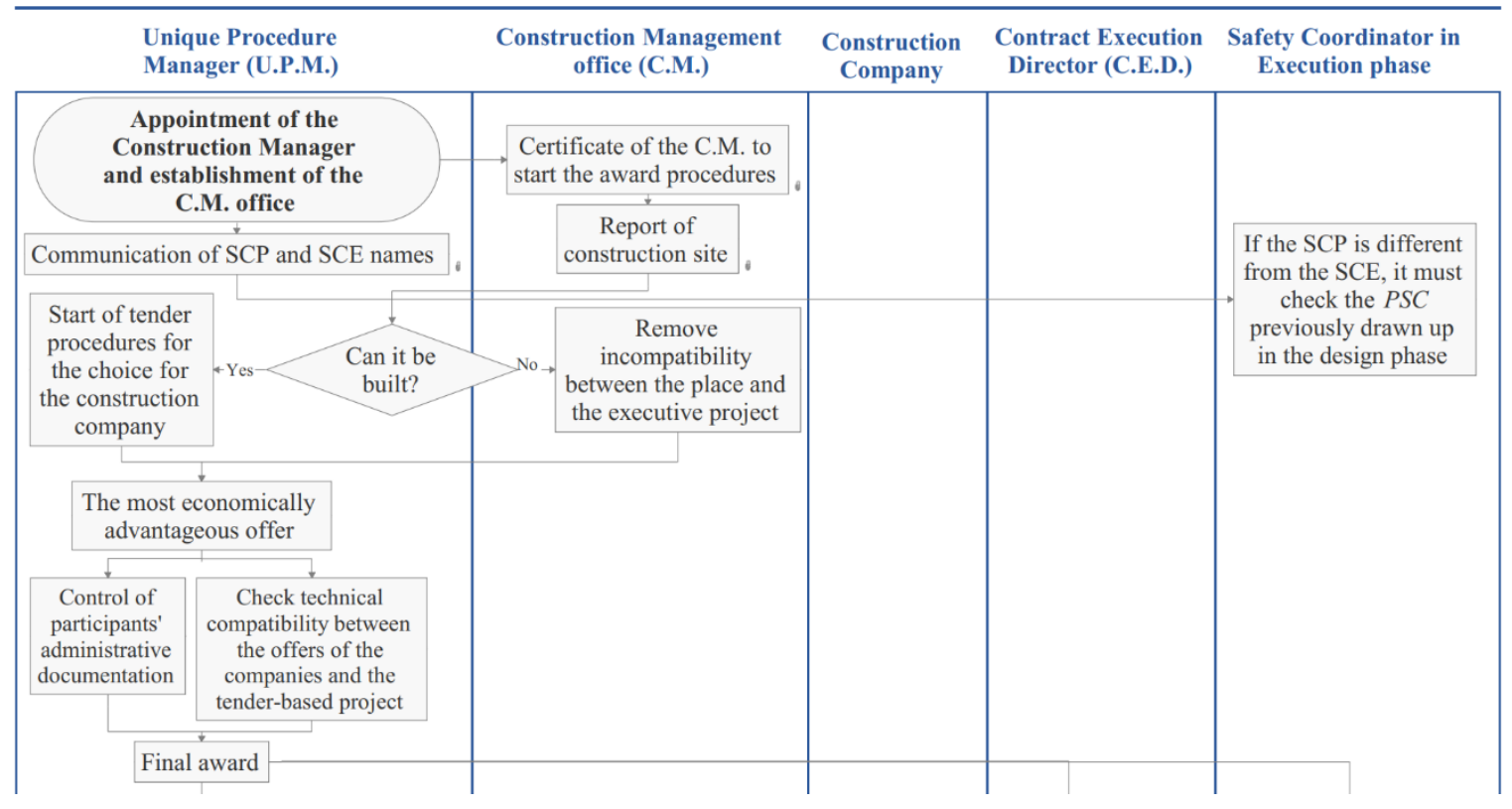

Figure 2. Initial part of the workflow performed: tender phase.

\section{USE AND CASE STUDY}

\subsection{Document Management System (DMS) Platform}

The digitization of processes aims at creating a shared and common working environment, which can facilitate communication between the parties. However, if not supported by an adequate contractual structure, it is not sufficient to achieve this goal. This innovation allows to structure new digital processes through a systematic acquisition of structured data at different stages of the process. There is a need for a standard to be referenced for data transmission and development of platforms that can provide guidelines and tools for the construction process. The digital platforms used to store data related to the accounting of work are electronic tools guaranteeing the authenticity, security, traceability, and origin of the information entered. The digital platform becomes the database of information related to site procedures.

Data sharing environment therefore allows for continuous interconnection and dialogue among stakeholders and those responsible for the related activities of the work. Simultaneous recording of site events allows operators to predict or identify situations of risk, non-compliance, or criticality of various kinds and to be able to take decisions in order to avoid negative outcomes by streamlining procedures.

\subsection{First Grade of Secondary School of Liscate: The Digital Construction Site}

The definition of workflows was performed as first step to the definition of a collaborative platform, where process flows were digitized, together with all the documents used and produced during the process. The proposed method was successfully applied on the construction of the Secondary School of Liscate, which is an example of the digitized management of a public work developed with the BIM methodology and the support of the digital platform AlFresco. The platform can be accessed through a web interface, and provides a repository for all documents, depending on the roles of the actors. Documents are divided in four categories: Work in progress, Shared, Published, Stored. AlFresco acts as a digital workspace, allowing the setting of 
workflows among the users; all users have different permissions to the workspace, depending on their role in the process. All the documents of the construction processes were stored in the platform, and processes of validation were digitized and performed directly through the platform, assuring compliance and transparency.

\section{CONCLUSIONS}

The goal of this paper was to provide an approach improving the control of all the figures involved in Construction Management and to digitally manage the entire documentation. The workflow also makes it possible to predict how each process must be carried out, how it must be verified and which documents must be submitted. The drafting of the flow is intended to generate a method that, through a schematization of the building process, can support Construction Management in the control of all actors and in the digital management of documentation. The provided case study resulted in a successful application of digital workflows for construction management; despite initial concerns, all the actors participated in the platform and learnt to properly manage digital flows and documentation management. Sharing all the documents of the process facilitated communication among stakeholders and avoided losses or mistakes in the interpretation. Interviews with all the involved stakeholders testified that the use of the platform was successful: the Municipality of Liscate has expressed the intention to proceed in the use of the platform for other projects. The proper application of the proposed method resulted in no controversies and no delays in the construction process.

The integration of this methodology in the public construction sector can enhance the transparency of procurement processes, guaranteeing an increase in efficiency, effectiveness, and affordability of the entire process, through parametric information models.

This change can consequently improve the control of design and construction costs, assuring compliance with the planned deadlines. The development of the contract through a digital process also facilitates the consistent sharing of information between all participants during each phase of the contract's execution.

\section{References}

Agliata, M., La direzione dei lavori dopo il nuovo codice degli appalti, Maggioli Editore, 2016.

ANAC Guidelines for Implementation of D. Lgs., No. 59, April, 2016.

Ciribini, A., ed., Il cantiere digitale, Società Editrice Esculapio, 2019.

Decree of Republic President No. 207 "Codice dei contratti pubblici relativi a lavori, servizi e forniture in attuazione delle direttive 2004/17/CE e 2004/18/CE", 5 October 2010.

Eastman, C. M., and Sacks, R., Relative Productivity in the AEC Industries in the US for On-site and Offsite Activities, Journal of Construction Engineering and Management, July, 2008.

Gottfried, A., Ergotecnica edile progettazione e programmazione operativa ed economica. Direzione dei lavori, contabilità e collaudi. Scelta delle macchine, Hoepli, 2013.

Gottfried, A., and Di Giuda, G. M., Ergotecnica edile, Società Editrice Esculapio, 2011.

Istat, Rapporto sulla competitività dei settori produttivi, 2018, retrieved from www.istat.it on May 2021.

Legislative Decree No. 50, "Codice dei contratti pubblici", 18 April 2016.

Malosetti, E., La direzione lavori di opere pubbliche, Maggioli Editore, 2019.

Marcandalli, G., Sanvito, L., Virtual Design and Construction a supporto del processo edilizio. Metodo digitalizzato di analisi e valutazione delle varianti in corso d'opera, Master's degree thesis, Politecnico di Milano, Lecco, 2020.

McKinsey, A future that works automation, employment, and productivity, 2017, retrieved from www.mckinsey.com on May 2021 .

Ministerial Decree No 49 "Approvazione delle linee guida sulle modalità di svolgimento delle funzioni del direttore dei lavori e del direttore dell'esecuzione ", 7 March 2018. 